\title{
MRSA-ST398 in livestock farmers and neighbouring residents in a rural area in Germany
}

\author{
B Bisdorff ${ }^{*}$, J Scholhölter ${ }^{1}$, K Claußen $^{2}$, M Pulz $^{2}$, D Nowak ${ }^{1}$ K Radon ${ }^{1}$ \\ From International Conference on Prevention \& Infection Control (ICPIC 2011) \\ Geneva, Switzerland. 29 June - 2 July 2011
}

\section{Introduction / objectives}

The aim of the study was to establish, for the first time the prevalence and risk factors associated with MRSAST398 carriage, a strain usually found in animals, in a rural population with occupational livestock contact as well as neighbouring residents.

\section{Methods}

A cross-sectional survey was out in a pig and poultry dense area in Germany. 2756 questionnaires and selfsampling nasal swabs were sent out in the winter of 2009/2010.

\section{Results}

Overall 1872 out of 2753 (response 70\%) people, aged between 26 and 53 years of age, took part in the study. Overall, $1.5 \%$ of the tested population without and $24 \%$ with occupational livestock contact tested positive for MRSA and MRSA-ST398 for the former; MRSA-ST398 only for the latter. The group without occupational livestock contact were 3.8 times (95\% CI 1.5-9.3) more likely to be colonized if a household member had livestock contact; 3.2 times (95\% CI 1.4-7.4) more likely if they regularly carried out private farm visits (e.g. to buy eggs or milk). In the group with occupational livestock contact, pig contact had an Odds Ratio of 7.1 (95\% CI 2.9-17.2) for MRSAST398 acquisition.

\section{Conclusion}

This is the first study establishing a MRSA prevalence of $1.5 \%$ within the general population without occupational livestock contact. The study furthermore confirmed already established risk factors for those with and those without occupational livestock contact. It also suggested

${ }^{1}$ Institute for Environmental\&Occupational Medicine, Universirt Hospital of Munich, LMU, Munich, Germany

Full list of author information is available at the end of the article private farms visits as new potential risk factor for MRSA colonization for the group without occupational contact. More research however into establishing the exact transmission routes and foremost into measures to prevent the spread of the bacterium in the farming environment is still required.

\section{Disclosure of interest}

None declared.

\section{Author details}

'Institute for Environmental\&Occupational Medicine, Universirt Hospital of Munich, LMU, Munich, Germany. ${ }^{2}$ Governmental Institute of Public Health of Lower Saxony, Hannover, Germany.

Published: 29 June 2011

doi:10.1186/1753-6561-5-S6-P169

Cite this article as: Bisdorff et al:: MRSA-ST398 in livestock farmers and neighbouring residents in a rural area in Germany. BMC Proceedings 2011 5(Suppl 6):P169.

Submit your next manuscript to BioMed Central and take full advantage of:

- Convenient online submission

- Thorough peer review

- No space constraints or color figure charges

- Immediate publication on acceptance

- Inclusion in PubMed, CAS, Scopus and Google Scholar

- Research which is freely available for redistribution

Submit your manuscript at www.biomedcentral.com/submit

\section{Biomed Central}

\section{() Biomed Central}

